\title{
Dietary crude protein levels during growth phase affects reproductive characteristics but not reproductive efficiency of adult male Japanese quails
}

\author{
Pâmela Lacombe Retes ${ }^{1}$, Danusa Gebin das Neves ${ }^{2}$, Laryssa Fernanda Bernardes ${ }^{2}$, \\ Victoria Veiga Alves ${ }^{1}$, Natália de Castro Gonçalves ${ }^{2}$, Diego de Rezende Lima ${ }^{2}$, \\ Renata Ribeiro Alvarenga ${ }^{2}$, Barbara Azevedo Pereira², \\ Alireza Seidavi ${ }^{3}$, and Márcio Gilberto Zangeronimo ${ }^{1, *}$
}

\section{* Corresponding Author: Márcio Gilberto Zangeronimo Tel: +55-35-3829-1471 \\ E-mail: zangeronimo@ufla.br}

${ }^{1}$ Department of Veterinary Medicine, Federal University of Lavras, Lavras, MG 37200 Brazil

2 Department of Animal Science, Federal University of Lavras, Lavras, MG 37200 Brazil

${ }^{3}$ Department of Animal Science, Rasht Branch, Islamic Azad University, Rasht, 4147654919, Iran

ORCID

Pâmela Lacombe Retes

https://orcid.org/0000-0001-6084-553X Danusa Gebin das Neves

https://orcid.org/0000-0002-5595-3381

Laryssa Fernanda Bernardes

https://orcid.org/0000-0002-2646-3754

Victoria Veiga Alves

https://orcid.org/0000-0002-7370-9518 Natália de Castro Gonçalves

https://orcid.org/0000-0002-7998-4625 Diego de Rezende Lima

https://orcid.org/0000-0002-1031-1940

Renata Ribeiro Alvarenga

https://orcid.org/0000-0002-4685-666X Barbara Azevedo Pereira

https://orcid.org/0000-0002-3614-7886 Alireza Seidavi

https://orcid.org/0000-0002-1903-2753

Márcio Gilberto Zangeronimo

https://orcid.org/0000-0002-3530-9345

Submitted Feb 8, 2021; Revised Apr 9, 2021; Accepted Aug 10, 2021
Objective: The objective was to evaluate the influence of different dietary crude protein $(\mathrm{CP})$ levels during the growth phase on reproductive characteristics and reproductive efficiency as well as the body development of adult male Japanese quail.

Methods: Three hundred one-day-old male quails were distributed into five treatments with diets containing different CP levels $(18 \%, 20 \%, 22 \%, 24 \%$, and $26 \%)$ in a completely randomized design, with six replicates of ten birds each. The CP diets were applied only during the growth phase (1 to 35 days). At 36 days of age, the birds were transferred to 30 laying cages with three males and nine females each, and all birds received the same diet formulated to meet production-phase requirements until 96 days of age.

Results: The growth rate of the birds increased linearly $(\mathrm{p}<0.01)$ with increasing dietary $\mathrm{CP}$, but the age of maximum growth decreased $(\mathrm{p}<0.05)$. At growth maturity, all birds had the same body weight $(p>0.05)$. At 35 days of age, higher weight gain was obtained $(p<0.05)$ with diets containing $22 \% \mathrm{CP}$ or higher. No effects on feed conversion were observed in this phase. The increase in dietary CP enhanced $(\mathrm{p}<0.01)$ nitrogen intake and nitrogen excretion but did not affect $(\mathrm{p}>0.05)$ nitrogen retention. Testis size, seminiferous tubular area, number of spermatogonia, and germinal epithelial height at 35 days of age increased linearly $(\mathrm{p}<0.05)$ with dietary CP, while the number of Leydig cells decreased $(\mathrm{p}<0.01)$. The Sertoli cell number at 60 days of age increased linearly $(p<0.01)$ with dietary CP. Dietary $\mathrm{CP}$ levels did not affect cloacal gland size, foam weight, foam protein concentration, semen volume, or flock fertility at 90 days of age.

Conclusion: Dietary CP concentration affected body and testicular development in male Japanese quails but did not affect reproductive efficiency.

Keywords: Fertility; Growth Curve; Quail Breeding; Semen Quality; Testicular Development

\section{INTRODUCTION}

Quails are bred worldwide for both meat and egg production because of their ease of handling, small size compared with chickens and broilers, precocious development, low space requirements, low investment requirement, and high egg production capacity and rates. In addition, quail breeding has been used as a good experimental model for bird research because of the birds' rapid growth, greater egg production, and shorter intervals between generations relative to other species.

Nutrition is a main factor affecting quail productive efficiency. Dietary crude protein $(\mathrm{CP})$ is an important source of amino acids that are used for maintenance, growth, and 
production demands [1]. During the growth phase, the presence of amino acids is directly related to bird body development [2], and both excesses and deficiencies in amino acids may impair the functions of the organs. Studies have shown that body development is highly correlated with reproductive organ development [3]. Delays in reproductive organ development caused by inadequate dietary CP levels may therefore be directly related to bird sexual maturity and reproductive performance [2].

Regarding quails' nutritional requirements, most current recommendations $[4,5]$ are based on the performances of commercial unsexed birds or female birds only. However, since males and females present different growth characteristics, their nutritional requirements should also differ. Male and female quails can be bred separately during the growing phase but not during the reproductive phase. To date, there is not enough information to clarify whether males should be fed different diets than females during the growth phase. It is known that in one-day-old chick production systems, most reproductive problems are due to factors related to males because they are present in smaller numbers than females [6]. Thus, different feeding programs considering sex differences could be adopted to increase reproductive indexes [7]. In broiler breeders, studies have shown that separate feeding arrangements for each sex resulted in improved reproductive indexes [3], but in quails, this practice has no proven positive results. Thus, the objective was to evaluate the influences of different dietary CP levels during the growth phase on reproductive characteristics and reproductive efficiency as well as on body development of male Japanese quail.

\section{MATERIALS AND METHODS}

\section{Animals and experimental design}

This experiment was performed between March and June 2018 at the Department of Animal Science of the Federal University of Lavras (UFLA), Lavras, state of Minas Gerais, Brazil. The Animal Research Ethics Committee approved all experimental procedures under protocol no. 057/2017.

The 300 male one-day-old Japanese quails (Coturnix coturnix japonica) in the experiment were housed in a masonry shed in 30 cages ( $50 \mathrm{~cm}$ wide $\times 70 \mathrm{~cm}$ deep $\times 25.5 \mathrm{~cm}$ high) during the growth phase ( 1 to 35 days). For the production phase ( 36 to 96 days), the three males with the live weight closest to the cage average were selected, transferred to a screened laying shed, and housed together with nine females in laying cages ( $32 \mathrm{~cm}$ wide $\times 38 \mathrm{~cm}$ deep $\times 16 \mathrm{~cm}$ high). The temperature and humidity in the sheds were monitored using thermohygrometers placed at bird height, which recorded the minimum and maximum temperature and humidity. The temperature was kept at $38^{\circ} \mathrm{C}$ during the first three days using a wood-burning stove and was decreased by $0.5^{\circ} \mathrm{C}$ each day until the birds were 28 days old [8]. The photoperiod was 24 hours light:0 hours dark (natural + artificial light with 60 W lamps) for the first two days of life, 23 hours light: 1 hour dark until day 15, then 14 hours light:10 hours dark until the end of the growth phase. At 36 days of age, the light period was increased by 30 min each day up to 17 hours light:7 hours dark, which was retained until the breeding period ended [9].

For both phases (growth and production), a completely randomized design was used, with five treatments and six replicates (cages). The treatments consisted of five dietary CP levels (18\%, 20\%, 22\%, 24\%, and 26\%) during the growth phase only; feeds were isoenergetic and isonutritious for the remaining nutrients. Diets were formulated based on the recommendations of Rostagno et al [5] by increasing or decreasing the recommended CP level $(22 \% \mathrm{CP})$ by $2 \%$ or $4 \%$. During the production phase, all birds received standard feed (18\%) formulated per the recommendations for that phase [5]. All diets were corn and soybean meal-based and formulated using the $\mathrm{CP}$ values obtained from their chemical analysis. Feed samples were also collected to determine the CP concentrations (Table 1). Feed and water were supplied ad libitum throughout the entire 96-day experimental period.

\section{Body development and performance}

On the first day of the experiment, two previously identified males per cage were individually weighed every three days until 60 days of age to determine the growth curve. The two birds' live weights were used to calculate the Gompertz curve, which was then used to determine the body weight at the growth maturity (A), growth rate (B), and age of maximum growth (M) [7]. The curve was calculated using Statistica 13.3, using the following model:

$$
W d=A \times e^{\left(-e^{(-B \times(d-M))}\right)}
$$

in which Wd is the weight at day $\mathrm{d}$ (in g); $\mathrm{A}$ is the body weight at growth maturity $(\mathrm{g})$; B is the growth rate $\left(\mathrm{d}^{-1}\right)$; and $\mathrm{M}$ is the age (d) of maximal growth (inflection point).

The birds were weighed at 1,14 , and 35 days old to determine weight gain. The supplied feed and leftovers were also weighed to determine feed intake. Feed conversion was calculated as the feed intake:weight gain ratio per period.

\section{Nitrogen balance}

At 33,34 , and 35 days of age, the total excreta were collected once daily to evaluate the nitrogen balance at the end of the growth phase. At the beginning and end of the collection period, the feed was weighed to determine intake. Collection trays were inserted under each cage and lined with resistant plastic to avoid contamination and loss of excreta. All collections began at 08:00. Feathers and feed particles were removed, 
Table 1. Calculated percentage compositions and nutrient levels in Japanese quail feed during the growth (1 to 35 days) and production (36 to 96 days) phases

\begin{tabular}{|c|c|c|c|c|c|c|}
\hline \multirow{2}{*}{ Variable } & \multicolumn{6}{|c|}{ Crude protein (\%) } \\
\hline & 18 & 20 & 22 & 24 & 26 & Production \\
\hline Corn & 56.30 & 52.40 & 48.55 & 44.70 & 40.80 & 53.00 \\
\hline Wheat meal & 2.00 & 2.00 & 2.00 & 2.00 & 2.00 & 3.00 \\
\hline Bicalcium phosphate & 1.240 & 1.192 & 1.145 & 1.098 & 1.050 & 1.06 \\
\hline Calcitic lime & 1.35 & 1.35 & 1.35 & 1.35 & 1.35 & 6.785 \\
\hline Mineral supplement ${ }^{1)}$ & 0.100 & 0.100 & 0.100 & 0.100 & 0.100 & 0.100 \\
\hline Vitamin supplement ${ }^{2)}$ & 0.100 & 0.100 & 0.100 & 0.100 & 0.100 & 0.100 \\
\hline DL-methionine (99\%) & 0.005 & 0.038 & 0.070 & 0.103 & 0.136 & 0.604 \\
\hline L-lysine (78\%) & 0.052 & 0.039 & 0.026 & 0.013 & 0.000 & 0.358 \\
\hline L-threonine (99\%) & 0.002 & 0.015 & 0.031 & 0.046 & 0.060 & 0.038 \\
\hline \multicolumn{7}{|l|}{ Calculated nutritional composition } \\
\hline Metabolizable energy (kcal/kg) & 2,900 & 2,900 & 2,900 & 2,900 & 2,900 & 2,800 \\
\hline Crude protein analyzed (\%) & 18.32 & 20.09 & 21.92 & 24.14 & 26.39 & 18.04 \\
\hline Calcium (\%) & 0.900 & 0.900 & 0.900 & 0.900 & 0.900 & 2.909 \\
\hline Available phosphorus (\%) & 0.333 & 0.333 & 0.333 & 0.333 & 0.333 & 0.303 \\
\hline Sodium $(\%)$ & 0.176 & 0.176 & 0.176 & 0.176 & 0.176 & 0.145 \\
\hline \multicolumn{7}{|l|}{ Amino acid/lysine } \\
\hline Lysine (\%) & 100 & 100 & 100 & 100 & 100 & 100 \\
\hline Methionine+cystine (\%) & 56 & 56 & 56 & 56 & 56 & 82 \\
\hline Threonine (\%) & 69 & 69 & 69 & 69 & 69 & 60 \\
\hline Tryptophan (\%) & 23 & 23 & 23 & 23 & 23 & 21 \\
\hline
\end{tabular}

${ }^{1)}$ Content per $\mathrm{kg}$ of feed (minimum for all elements): $10 \mathrm{mg}$ of copper, $50 \mathrm{mg}$ of iron, $1.2 \mathrm{mg}$ of iodine, $80 \mathrm{mg}$ of manganese, $0.28 \mathrm{mg}$ of selenium and 60 mg of zinc.

${ }^{2)}$ Content per $\mathrm{kg}$ of feed: $0.8 \mathrm{mg}$ of folic acid, $35 \mathrm{mg}$ of pantothenic acid, $1.0 \mathrm{mg}$ of biotin, $40 \mathrm{mg}$ of niacin, $11,500 \mathrm{IU}$ of vitamin $\mathrm{A}_{3} 3.0 \mathrm{mg}$ of vitamin $\mathrm{B}_{1}, 22$ IU of vitamin $E_{1} 0.6 \mathrm{mg}$ of vitamin $B_{12}, 4.4 \mathrm{mg}$ of vitamin $B_{2}, 10.0 \mathrm{mg}$ of vitamin $B_{6}, 2,100 \mathrm{Ul}$ of vitamin $D_{3}, 1.5 \mathrm{mg}$ of vitamin $K_{3}$, and $125 \mathrm{mg}$ de antioxidant.

and excreta were placed in plastic bags and stored at $-20^{\circ} \mathrm{C}$ until the end of the collection period. The excreta were then thawed, homogenized, and weighed. Aliquots of $300 \mathrm{~g}$ were removed and predried in a forced air circulation oven $\left(55^{\circ} \mathrm{C}\right)$ for 72 hours. The samples were again weighed to determine the predry matter and then ground using a knife mill equipped with a 2-mm sieve. Excreta and feed samples were analyzed to determine dry matter and nitrogen concentrations [10]. The nitrogen intake and excreta were quantified based on the results, and the percent nitrogen retained was calculated.

\section{Testicular development}

At 35 days of age, before transfer to the production phase housing, two males from each experimental unit were selected based on their average weight, euthanized by cervical dislocation and exsanguination, and dissected for testicular harvesting. At 60 days of age, the same procedure was performed on one male from each experimental unit. The right and left testes were removed, weighed separately, and mea- sured (width $\times$ thickness $\times$ height) using a digital pachymeter (Digimess, São Paulo, Brazil). Testicular weight was calculated as the sum of the weight of the right and left testes. Testicular volume was calculated using the equation $V=$ $4 \div 3 \pi \mathrm{ab}^{2}$, where $a$ is half the testis height and $b$ is half the testis width [11]. The gonadosomatic index, which is the percentage of body weight contributed by the gonads, was estimated using the equation $G I=([W T l+W T r] / L W) \times 100$, where $W T l$ is the left testis weight, $W T r$ is the right testis weight, and LW is the live weight. After measuring these parameters, the testes were fixed in Bouin's solution for approximately 12 hours at ambient temperature and then washed in $70 \%$ alcohol for subsequent histological analysis [12].

\section{Histological analysis}

The testes were histologically analyzed at the Laboratory of Histology and Immunohistochemistry of the Department of Animal Science of UFLA. First, the testes were dehydrated 
in a graded ethanol-xylol series and embedded in paraffin. Sections ( $5 \mu \mathrm{m}$ thick) were obtained, suspended in a water bath at approximately $37^{\circ} \mathrm{C}$, mounted on silanized histological slides, and dried in an oven at $37^{\circ} \mathrm{C}$ overnight. The samples were then deparaffinized, rehydrated in a xylol-ethanol series, and stained with hematoxylin-eosin [13].

Seminiferous tubule images were analyzed at $400 \times$ magnification using an Olympus CX31 microscope (Olympus, Tokyo, Japan) coupled to an Altra SC30 digital camera (Olympus, Japan) and Axio Vision software (Carl Zeiss, Oberkochen, Germany). In each section, the largest and smallest diameters of ten random round-shaped tubules were measured to calculate the seminiferous tubular area using the equation $A=\pi r^{2}$, where $r$ is the tubule radius calculated from the average of the largest and smallest diameters. The seminiferous epithelial height was obtained by performing seven measurements per tubule and analyzed to calculate the area.

\section{Immunohistochemistry}

Immunohistochemical analyses were performed in the Laboratory of Histology and Immunohistochemistry of the Department of Animal Science of UFLA. Slides were prepared as described for the histological analyses per Suvarna et al [13] with some adaptations. All slides were incubated in a humidified chamber, and all washes consisted of three consecutive immersions for five minutes in $0.1 \mathrm{M}$ phosphatebuffered saline (PBS) at pH 7.2. Endogenous peroxidase activity was blocked by incubation in Peroxidase Block (K4011, DakoCytomation, USA) for 30 minutes and washed in PBS. Nonspecific antibody binding was blocked by incubating the sections with Block Serum (X0909, DakoCytomation, USA) for 15 minutes. The histological sections were then washed again in PBS, incubated for 2 hours with mouse anti-PCNA monoclonal primary antibody (M0879, Dako-
Cytomation, USA) for staining the Spermatogonia, or incubated for 2 hours with rabbit anti-Androgen receptor polyclonal antibody (AB168834, Abcam, Waltham, MA, USA) for detection of Leydig cells [14]. After incubation the histological sections were washed in PBS, incubated for 15 minutes in Biotinylated Link Universal (K0690 DakoCytomation, USA), washed again in PBS for 5 minutes, and incubated in Streptavidin-HRP (K0690 DakoCytomation, USA) for 15 minutes per the recommendations from the LSAB+System/HRP anti-rabbit and anti-mouse secondary antibody kit (K0690, DakoCytomation, USA). After washing, the histological sections were developed enzymatically using 3,3-diaminobenzidine tetrahydrochloride (DakoCytomation, USA) and immersed in distilled water to stop the reaction after 30 seconds (samples from birds aged 35 days) or after one minute (samples from birds aged 60 days). The slides were then counterstained with hematoxylin and mounted under a coverslip.

Sertoli cells were identified in counterstained histological section slides of the PCNA test through their morphology. They are tall simple columnar cells, which span from the basement membrane to the lumen surrounded by the proliferating and differentiating germ cells. After counting the number of Sertoli cells per tubule the percentage of proliferating spermatogonia were determined in ten tubule sections per testis and observed at $400 \times$ magnification using a light microscope (Olympus CX31; Olympus, Japan). The Sertoli cell number per area $\left(10,000 \mu \mathrm{m}^{2}\right)$ was calculated using the tubular area. The number and percentage of proliferating spermatogonia were determined by counting the stained cells relative to the total number of cells located closer to the basal membrane (Figure 1).

The number of Leydig cells and the tubular and intertubular areas were evaluated at $1,000 \times$ ( 35 days of age) $400 \times$ (60 days of age) using an Olympus CX31 microscope (Olym-
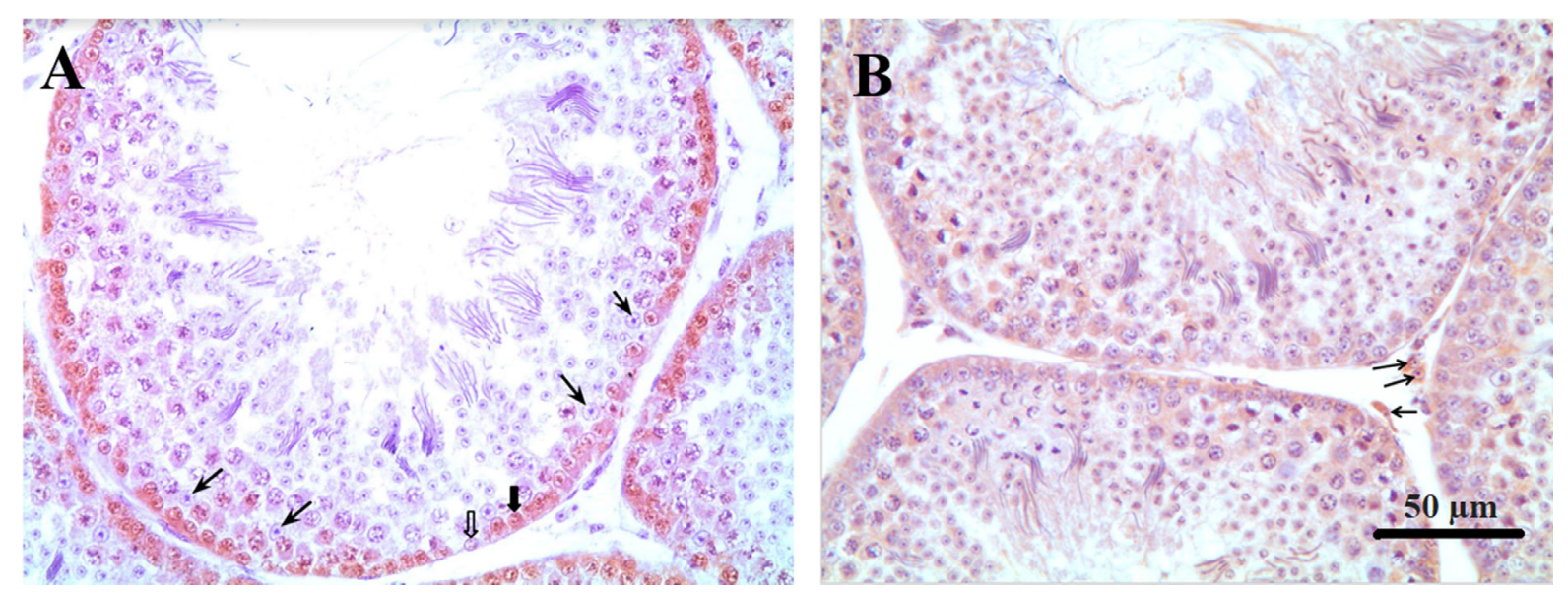

Figure 1. Immunohistochemical localization of spermatogonia; Sertoli and Leydig cells in testicle of Japanese quail at 60 days of age. (A) Thin arrows: Sertoli cells. Thick arrow: stained spermatogonia. Unfilled arrow: unstained spermatogonia. (B) Arrows: Leydig cells (magnification, $\times 400$ ). 
pus, Japan) coupled to an Altra SC30 digital camera (Olympus, Japan) in Axio Vision software (Carl Zeiss, Germany). Ten fields randomly distributed in the testicular parenchyma were evaluated on a projected grid in Image version $1.50 \mathrm{i}$ (NIH, Bethesda, MD, USA), and 102 intersection points were considered. The Leydig cell number per area $(10,000$ $\mu \mathrm{m} 2)$ was calculated using the proportion of Leydig cells per intertubular area and the intertubular area.

\section{Fertility test}

On days 59 and 60 of the experiment, all eggs were collected from each cage. Eggs that were cracked, broken, dirty, too large, or too small were discarded, and the remainder $(\mathrm{n}=$ $100 /$ treatment) were labeled and stored for 24 hours at $20^{\circ} \mathrm{C}$. The eggs were then weighed, and ten eggs were selected per cage based on average weight. The selected eggs were sterilized with a 2:1 formaldehyde (37\%):potassium permanganate (99\%) solution [15] and incubated at $37.5^{\circ} \mathrm{C}$ and $60 \%$ humidity [16] in an automatic incubator (Luna 480; ChocMaster, Piraquara, Brazil). The automatic egg-turning tray turned the eggs every two hours until day 15 of incubation [17]. After 21 days of incubation, the numbers of hatched and fertilized but unhatched eggs were counted, and percent fertility was calculated.

\section{Semen quality}

Semen quality was evaluated from one male per cage. From day 50 of the experiment, semen was collected every two days via dorsal-abdominal massage.

Semen was evaluated with or without the presence of foam [18] from the two remaining quails in each experimental unit. Foam was collected from each male's cloacal gland at days 80,81 , and 82 of the experiment at 08:00 and 16:00 each day by gently squeezing the cloacal gland on each side. After collection, the foam was stored in Falcon tubes at $-20^{\circ} \mathrm{C}$. At the end of the collection period, the samples obtained on the previous days were thawed at ambient temperature and diluted to 1:4 (foam:saline) in saline solution $(0.9 \%)$. The samples were then centrifuged at 3,000 g for $45 \mathrm{~min}$ (Sorvall ST 16 Centrifuge; Thermo Fisher Scientific, Waltham, MA, USA). The supernatant was collected and stored at $-80^{\circ} \mathrm{C}$ until semen quality analysis.

Beginning at 90 days of age, the bird semen was collected three times at 3-day intervals per Burrows and Quinn [19]. Before collection, the feathers in the pericloacal region were removed, and the cloacal gland was measured (width $\times$ thickness $\times$ height) using a digital pachymeter (Digimess, São Paulo, Brazil) to calculate the cloacal gland area (GA) using the equation $\mathrm{GA}=W \times H$, where $\mathrm{W}$ is the lateral width and $\mathrm{H}$ is the dorsoventral height [20].

Foam was removed from the cloacal gland during semen collection. The birds were massaged dorsally, beginning near the wing base and ending near the cloaca, with the standard six movements per animal. Slight pressure was then applied with the fingers on the base of the phallus and on the ampoules of the vas deferens to discharge the semen. The seminal content was collected in graduated capillary tubes, where its volume was measured, and then immediately diluted to $1: 1$ (semen:saline) in saline solution (0.9\%). A $1 \mathrm{~mL}$ aliquot of solution was diluted with $499 \mathrm{ml}$ of formalin for subsequent sperm concentration analysis, which was performed using a Neubauer chamber. Another $1 \mathrm{~mL}$ aliquot was diluted with $98 \mathrm{~mL}$ of $0.9 \%$ saline solution or $0.9 \%$ saline solution $+5 \%$ foam [21].

Immediately after dilution in saline solution or saline solution + foam, three trained evaluators blinded to the sample identity evaluated the sperm motility and movement intensity in three subsamples mounted between glass slides and coverslips at $37^{\circ} \mathrm{C}$, observing them at $200 \times$ magnification using a light microscope (Olympus CX31; Olympus, Japan). Sperm motility was expressed as the percentage of motile spermatozoa, and movement intensity was classified from 0 to 5 , with 0 being the lowest and 5 the highest.

Sperm viability was evaluated by mixing one drop of semen with one drop of eosin-nigrosin on glass slides and observing the mixture at $400 \times$ magnification using a light microscope (Olympus CX31; Olympus, Japan). The numbers of living (no color) and dead (pink) cells were counted, and sperm viability was calculated as living cells/total cells $\times 100$.

\section{Statistical analysis}

The Gompertz curve parameters (A, B, and $\mathrm{M}$ ) obtained for each experimental unit and the male reproductive performance and quality data were checked for normality (Anderson-Darling), homoscedasticity (Breusch-Pagan), and independence of error (Durbin-Watson). When the assumptions of normality were met, an analysis of variance (one-way analysis of variance [ANOVA]) was performed, and a regression analysis was performed for the protein levels. Only for live weight a two-way ANOVA (CP levels $\times$ age of birds) was performed. When a linear regression could not be fit $\left(\mathrm{R}^{2}<0.70\right)$, a broken-line analysis was performed to determine the best protein level [22]. When a curve could not be fit by broken-line analysis, the averages were compared using the Student-Newman-Keuls (SNK) test at $\mathrm{p} \leq$ 0.05 . When the ANOVA assumptions were unmet and the Box-Cox and Johnson data transformations could not be used to normalize the data, the data were subjected to a nonparametric analysis, and the averages were compared using the Kruskal-Wallis test. The fetility test was analyzed by a binomial score ( 1 or 0 ) based on the presence or absence of fertilization. All statistical analyses were performed using Statistica 13.3 and Action 3.5 software. 


\section{RESULTS}

Growth characteristics and performance

The different dietary CP levels in the growth diets resulted in different growth patterns in male quails (Table 2; Figure $2)$. The growth rate increased linearly $(\mathrm{p}<0.01)$, and the age of maximum growth (curve inflection point) decreased ( $\mathrm{p}<$ 0.05 ) with increasing dietary CP up to $22 \%$ CP (Figure 3 ). No effect was observed on body weight at maturity $(p>0.05)$.

Live weight from the second to the seventh week of the birds' lives was affected by the inclusion of CP (Table 3); $23 \%$ $\mathrm{CP}$ or higher resulted in greater live weights up to 36 days of age (Figure 4). To obtain greater weights at 42 and 48 days of age, $23.5 \% \mathrm{CP}$ is recommended.

Diets with $24 \%$ and $26 \% \mathrm{CP}$ resulted in greater weight gain and improved feed conversion up to 14 days of age $(\mathrm{p}<0.01)$ (Table 4). Feed intake was lower in the $18 \%$ CP group ( $\mathrm{p}<$ 0.01 ). Considering the whole growth phase (1 to 35 days), diets with $22 \% \mathrm{CP}$ or more resulted in less weight gain $(\mathrm{p}<$ $0.01)$. No effect on feed conversion was observed in this phase ( $>0.05$ ). At the end of the growth phase (33 to 35 days of age), both nitrogen intake and nitrogen excretion increased linearly with increasing dietary $\mathrm{CP}(\mathrm{p}<0.01)$. No differences in nitrogen retention were observed ( $\mathrm{p}>0.05)$.

\section{Reproductive characteristics and reproductive efficiency}

At 35 days of age, anatomical and histological evaluations of the quail testes were affected by the dietary CP level $(\mathrm{p}<0.01)$ (Table 5). The sizes (height, width, and thickness), as well as weight and volume, of the right and left testes and seminiferous tubular areas increased linearly $(\mathrm{p}<0.01)$ with increasing dietary $\mathrm{CP}$ levels (Figure 5). Germinal epithelial height increased $(\mathrm{p}<0.01)$ only up to $22 \% \mathrm{CP}$ (Figure 6). A higher intertubule: tubule ratio was observed $(\mathrm{p}<0.01)$ in the $24 \%$ and $26 \% \mathrm{CP}$ groups. There was a linear effect $(\mathrm{p}<0.01)$ of dietary $\mathrm{CP}$ on the number of spermatogonia and Leydig cells in the testis.

At 60 days of age, a linear increase $(\mathrm{p}<0.01)$ in Sertoli cell numbers was observed with increasing $\mathrm{CP}$ levels in the diet. Higher Leydig cell numbers were observed $(p<0.01)$ with
$18 \%$ CP and more spermatogonia/area were observed with $24 \%$ and $26 \% \mathrm{CP}(\mathrm{p}<0.05)$.

At 90 days of age, the $\mathrm{CP}$ levels in the growth diet did not affect cloacal gland size, foam weight and protein concentration, semen volume and quality, or flock fertility $(\mathrm{p}>0.05)$ (Table 6).

\section{DISCUSSION}

Although dietary CP levels affected body development, Sertoli cell numbers, and the number of spermatogonia in male Japanese quails, their reproductive efficiency during the production phase was unaffected. These results suggest that the lowest CP level tested (18\% CP) or the CP level recommended for females $(24 \%)[4,23]$ can be used in breeder flocks.

Male fertility is essential to one-day-old chick production systems and is directly related to spermatogenesis. Spermatozoid production, in turn, depends on the Sertoli cell number and activity and the number of proliferating spermatogonia [24]. In the present study, the increased Sertoli cell numbers and the number of spermatogonia in adult birds in response to increased dietary $\mathrm{CP}$ during the growth phase did not affect flock fertility. This may have been because male Japanese quails naturally present high fertility rates (higher than 90\%), even with decreased levels of dietary amino acids (Table 6). In addition, the similar sperm concentrations among birds receiving diets with different $\mathrm{CP}$ levels indicate that sperm production was regulated by physiological mechanisms [25]. These authors suggest that follicle-stimulating hormone (FSH) secretion is regulated by activin and inhibin. In males, FSH controls inhibin secretion through unknown mechanisms. This hypothesis of physiological regulation can be reinforced by the fact that increases in the number of Sertoli cells and spermatogonia were not associated with increases in the sperm concentration of the birds (Table 5).

During the growth phase, rapid body development is directly related to reproductive organ development [26]. Thus, the supply of amino acids during this phase may affect bird growth. In the present study, an increase of up to $24 \%$ in dietary CP accelerated body development and led to earlier maturity of growth. This rapid development resulted in in-

Table 2. Growth characteristics obtained from the Gompertz curve for male Japanese quails between 1 and 60 days old receiving diets with different crude protein levels during the growth phase $(n=12)$

\begin{tabular}{|c|c|c|c|c|c|c|c|}
\hline \multirow{2}{*}{ Variable } & \multicolumn{5}{|c|}{ Crude protein (\%) } & \multirow{2}{*}{ SEM } & \multirow{2}{*}{ p-value } \\
\hline & 18 & 20 & 22 & 24 & 26 & & \\
\hline Body weight at growth maturity (g) & 149 & 147 & 146 & 141 & 141 & 0.42 & 0.55 \\
\hline Growth rate & $0.057 *$ & 0.069 & 0.078 & 0.089 & 0.091 & 0.01 & $<0.01$ \\
\hline Age at maximum growth (d) & $25.0 * \star$ & 16.0 & 14.1 & 12.6 & 12.7 & 0.35 & 0.02 \\
\hline
\end{tabular}

SEM, standard error of the mean

* Linear effect $(p<0.01)$.

** Linear response plateau $(p<0.05)$ 


\section{$18 \%$ crude protein}

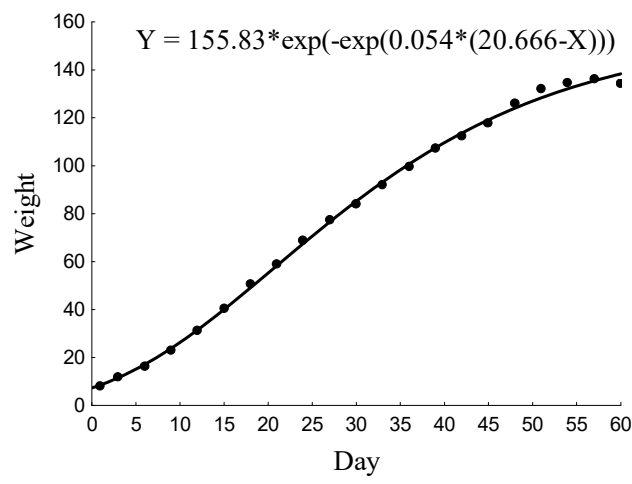

$22 \%$ crude protein

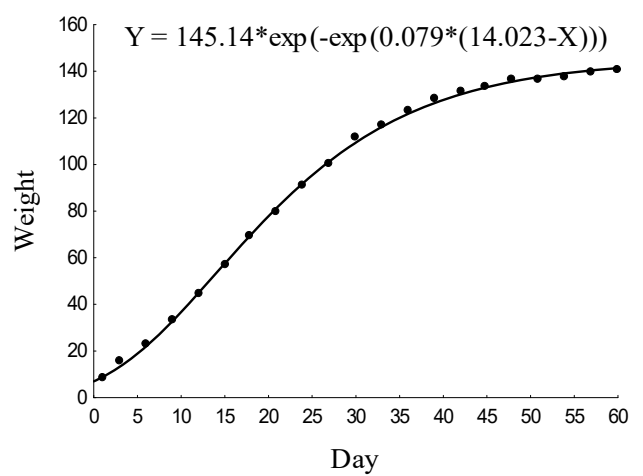

$20 \%$ crude protein

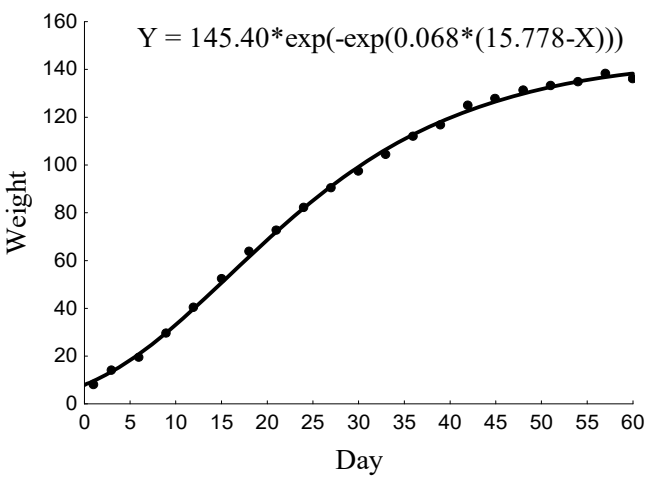

$24 \%$ crude protein

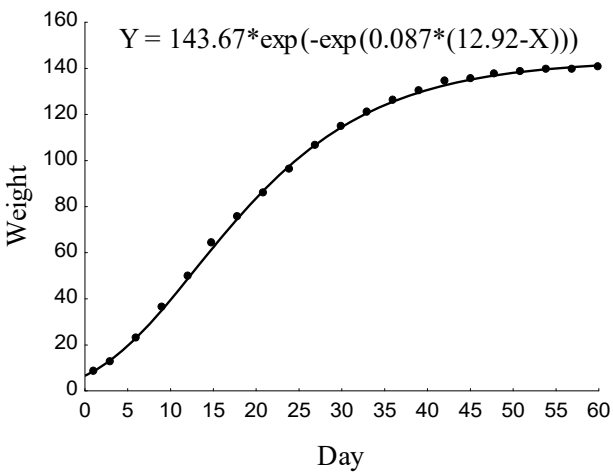

$26 \%$ crude protein

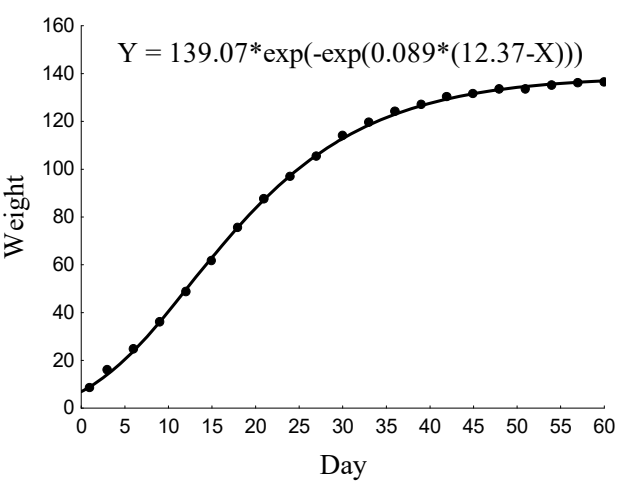

Figure 2. Gompertz model growth curves for male Japanese quails receiving diets with different crude protein levels during the growth phase $(\mathrm{n}=$ 12).

creased testicular size and gonadosomatic index at the end of the growth phase (35 days of age), but not at 60 days of age. The reduction in Leydig cell concentration per testicular unit observed with increased CP in the diet suggests that testicular enlargement is not related to the number of Leydig cells but only to the number of tubular cells (spermatogonia and testis). This hypothesis is reinforced by the increase in the tubule: intertubule ratio stimulated by the increase in dietary CP. This could be related to an earlier reproductive age in males. In females, the increased body weight resulting from increased dietary $\mathrm{CP}$ also resulted in faster development of sex organs, decreasing the age of onset of sexual activity [2]. Therefore, using similar diets (with $24 \% \mathrm{CP}$ ) for males and females during the growth phase may benefit the reproductive system because it may lower the age of onset of reproductive activity. In addition, using similar diets for both males and females provides a greater ease of bird handling.

Overall, the amino acid supply should first meet the maintenance requirements, followed by the body development and reproductive activity requirements [1]. In birds, excess 

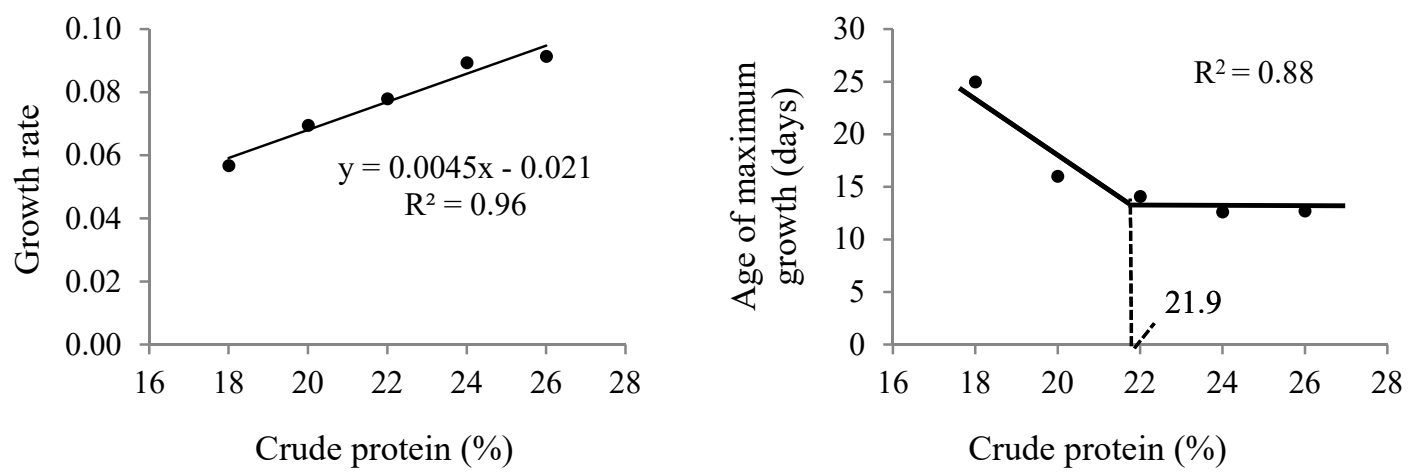

Figure 3. Growth characteristics obtained from the Gompertz curve for male Japanese quails, aged 1 to 60 days, receiving diets with different crude protein levels during the growth phase $(n=12)$.

Table 3. Live weight of male Japanese quails receiving diets with different crude protein levels during the growth phase $(n=12)$

\begin{tabular}{|c|c|c|c|c|c|c|c|c|c|}
\hline \multirow{2}{*}{ Age (d) } & \multicolumn{5}{|c|}{ Crude protein (\%) } & \multirow{2}{*}{ SEM } & \multicolumn{3}{|c|}{ p-value } \\
\hline & 18 & 20 & 22 & 24 & 26 & & Protein & Day & Prot×Day \\
\hline 6 & 16.3 & 19.5 & 22.9 & 22.7 & 24.6 & 3.16 & $<0.01$ & $<0.01$ & $<0.01$ \\
\hline 15 & $40.5^{\star}$ & 52.2 & 57.1 & 63.7 & 61.6 & & & & \\
\hline 21 & $58.8^{\star}$ & 74.6 & 79.7 & 86.1 & 87.6 & & & & \\
\hline 27 & $77.2^{\star}$ & 96.4 & 100.6 & 106.1 & 107.2 & & & & \\
\hline 36 & $91.4^{\star}$ & 111.1 & 113.8 & 119.9 & 122.0 & & & & \\
\hline 42 & $112.4^{\star \star}$ & 124.9 & 131.7 & 134.4 & 130.2 & & & & \\
\hline 48 & $125.9 * \star$ & 131.3 & 136.7 & 137.6 & 133.3 & & & & \\
\hline 54 & 132.5 & 134.7 & 137.9 & 135.0 & 135.1 & & & & \\
\hline 60 & 134.2 & 135.9 & 140.4 & 135.4 & 136.5 & & & & \\
\hline
\end{tabular}

SEM, standard error of the mean.

* Linear response plateau $(p<0.01)$

** Quadratic effect $(p<0.01)$.

amino acids are deaminated, and excess nitrogen is mainly eliminated as uric acid [27]. In Japanese quails, bodily differences between males and females are evident only from 35 days of age when the production phase begins $[4,23]$. However, growth decelerates (age of maximum growth) in males at approximately 13 days of age, whereas for females, it de-

Table 4. Performance and nitrogen balance of male Japanese quails receiving diets with different crude protein levels during the growth phase (n $=6)$

\begin{tabular}{|c|c|c|c|c|c|c|c|}
\hline \multirow{2}{*}{ Variable } & \multicolumn{5}{|c|}{ Crude protein (\%) } & \multirow{2}{*}{ SEM } & \multirow{2}{*}{ p-value } \\
\hline & 18 & 20 & 22 & 24 & 26 & & \\
\hline \multicolumn{8}{|l|}{1 to 14 days } \\
\hline Feed intake (g) & $65.1^{\mathrm{a}}$ & $86.2^{b}$ & $88.6^{b}$ & $89.4^{b}$ & $94.7^{\mathrm{b}}$ & 3.78 & $<0.01$ \\
\hline Feed conversion & $2.65^{a}$ & $2.45^{\mathrm{ab}}$ & $2.29^{b}$ & $1.96^{\mathrm{c}}$ & $2.07^{c}$ & 0.11 & $<0.01$ \\
\hline \multicolumn{8}{|l|}{1 to 35 days } \\
\hline Feed conversion & 3.46 & 3.29 & 3.25 & 3.22 & 3.25 & 0.06 & 0.07 \\
\hline \multicolumn{8}{|l|}{ Nitrogen balance at 35 days } \\
\hline $\mathrm{N}$ ingested (mg/bird/d) & $0.41^{\star}$ & 0.49 & 0.54 & 0.59 & 0.66 & 0.01 & $<0.01$ \\
\hline N excreted (mg/bird/d) & $0.19 * \star$ & 0.25 & 0.30 & 0.34 & 0.40 & 0.01 & $<0.01$ \\
\hline $\mathrm{N}$ retained (mg/bird/d) & 0.22 & 0.23 & 0.25 & 0.25 & 0.26 & 0.01 & 0.32 \\
\hline
\end{tabular}

SEM, standard error of the mean.

${ }^{a-c}$ Means followed by different letters within the same row differ significantly by the Student-Newman-Keuls test $(p<0.05)$.

* Linear effect $(p<0.05) . y=0.059 x+0.365 ; R^{2}=0.99$.

** Linear effect $(p<0.05) . y=0.049 x+0.153 ; R^{2}=0.98$. 
15 days

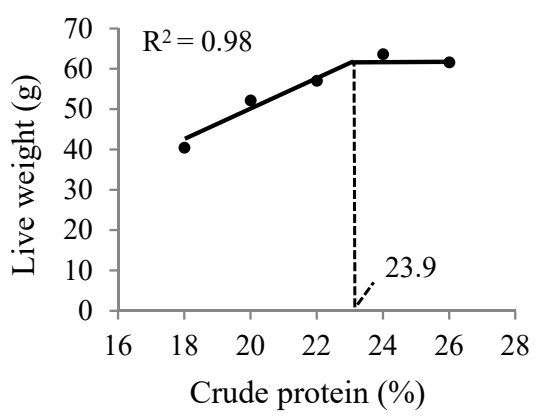

27 days

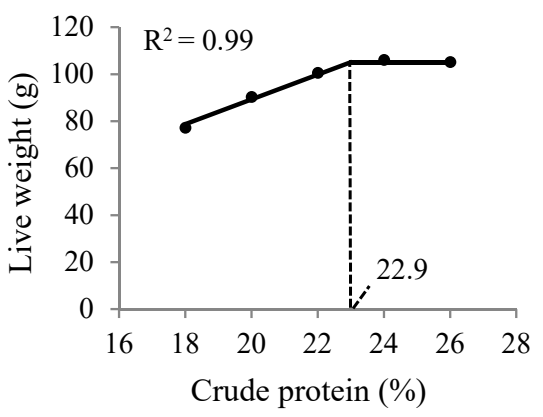

42 days

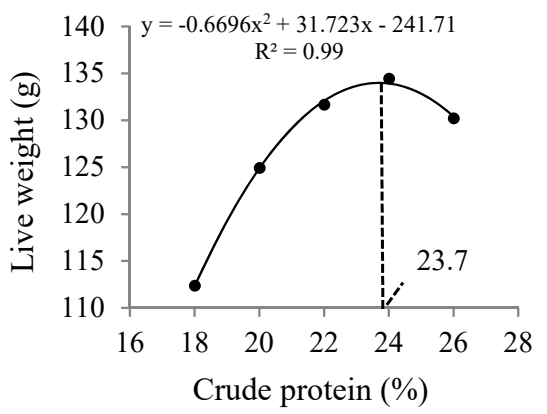

21 days

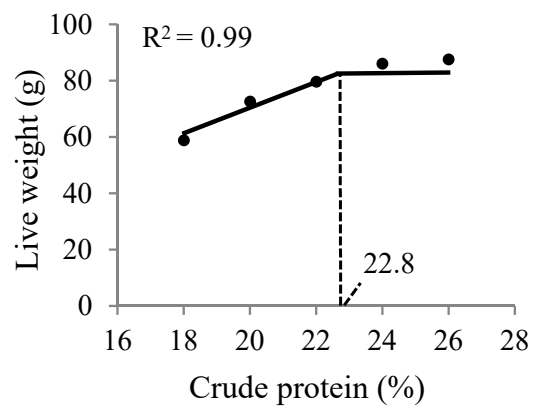

36 days

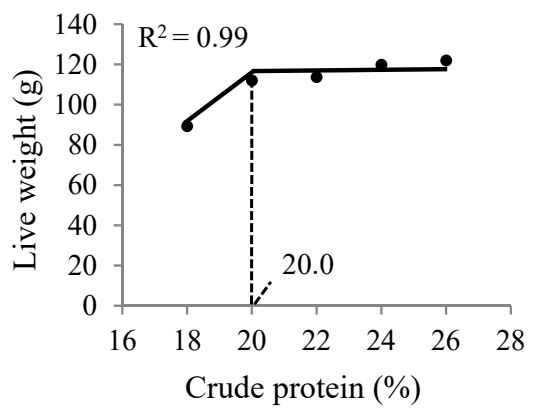

48 days

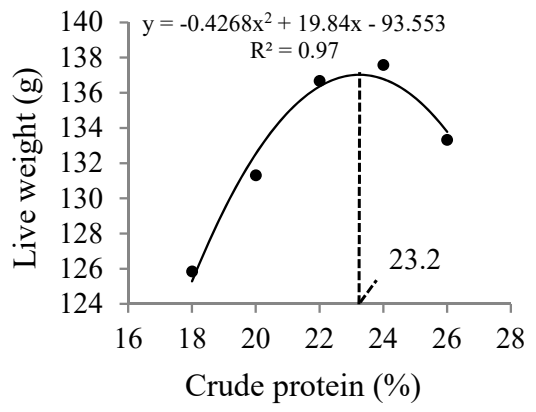

Figure 4. Live weight of male Japanese quails, at different ages, receiving diets with different crude protein levels during the growth phase $(n=$ 60).

celerates at approximately 23 days of age on diets containing $24 \%$ CP, as recommended by the National Research Council (NRC [4]). In this study, growth decelerated between 13 and 14 days of age on diets with CP levels between $22 \%$ and $26 \%$. These results indicate that phased nutritional management during bird development may be more effective. Rostagno et al [23] recommended that nutrition in Japanese quails be managed in two phases: chicks (1 to 14 days) and growers (15 to 35 days). Because males present lower growth rates than females, especially from 15 to 35 days of age, these nutritional requirements are likely overestimated for males. This explains the increased nitrogen excretion resulting from increased dietary CP intake (Table 4). The absence of significant differences in nitrogen retention indicates that the amino acid supply in diets with $18 \% \mathrm{CP}$ met the birds' maintenance and growth requirements at the end of the growth phase. Live weight gain during the last week of growth (27 to 35 days of age) was similar among the groups with different dietary $\mathrm{CP}$ levels (13 to 15 grams).

In this study, the live weights of 15-day-old males increased linearly with increasing dietary $\mathrm{CP}$, reaching the optimal point at $23.9 \% \mathrm{CP}$ (Figure 4 ). This is consistent with the performance data for this phase (1 to 14 days), which showed that diets with $24 \%$ and $26 \%$ CP resulted in more bird weight gained and lower feed conversion (Table 4). In this case, diets with lower CP levels may have limited bird growth because of their lower amino acid supplies. Karaalp [28] suggested that all essential amino acid levels are sufficient in the $24 \%$ 
Table 5. Growth characteristics and histological analyses of the testes of male Japanese quails aged $35(n=12)$ and $60(n=6)$ days receiving diets with different crude protein levels during the growth phase

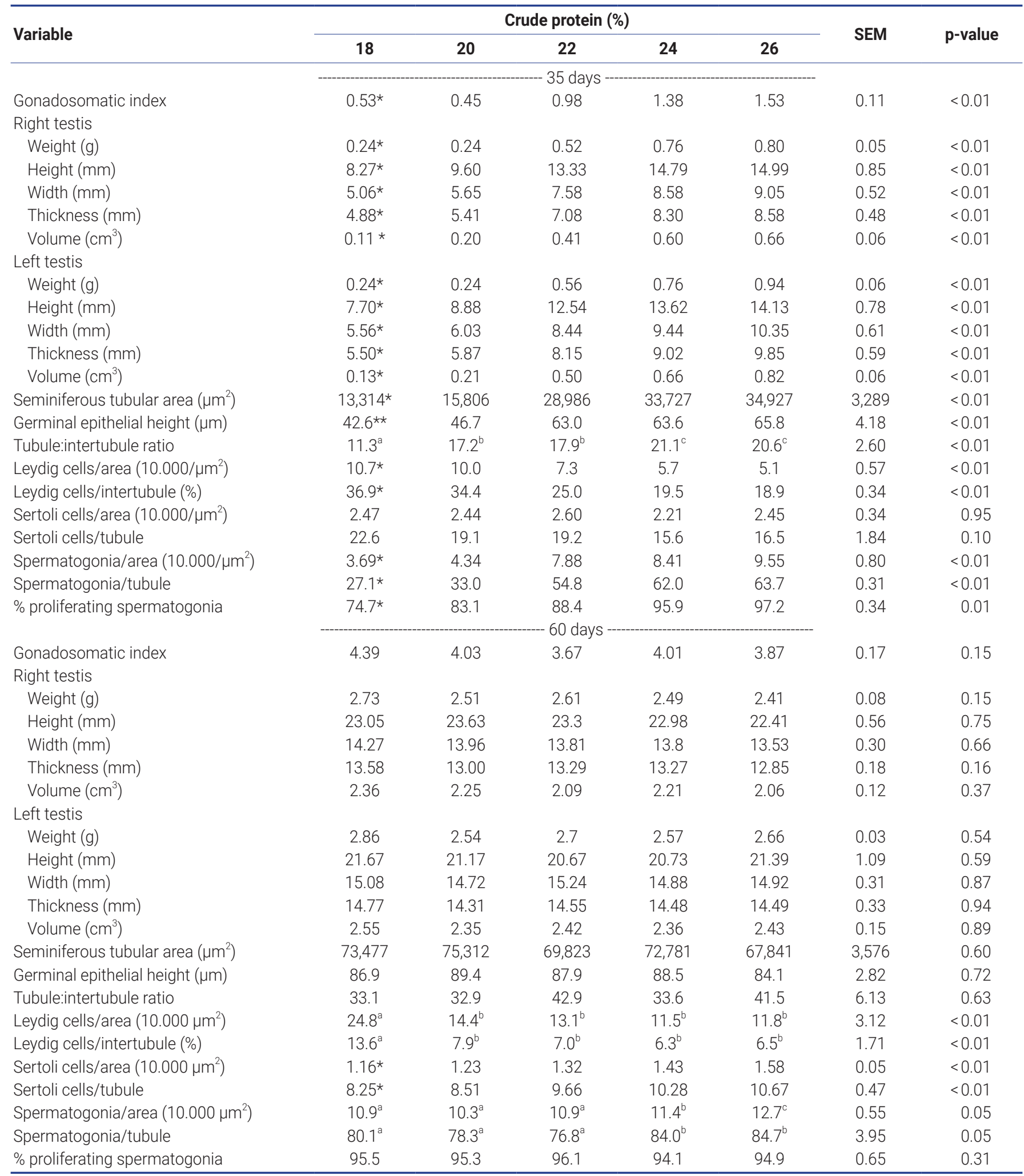

SEM, standard error of the mean.

* Linear effect $(p<0.01)$. ${ }^{*}$ Linear response plateau $(p<0.01)$.

a,b Means followed by different letters within the same row differ significantly by the Student-Newman-Keuls test $(p<0.05)$. 

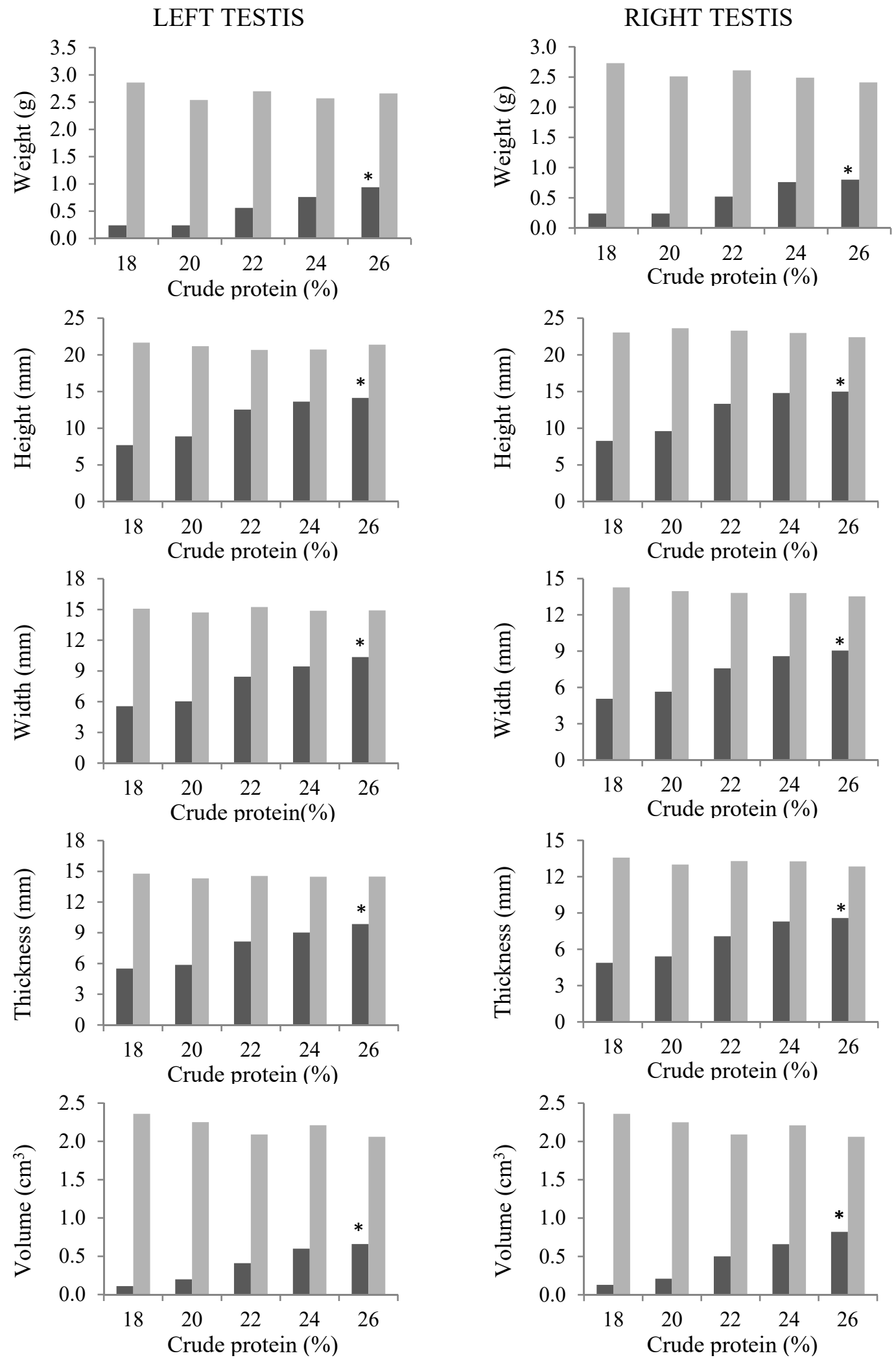

-35 days of age $\quad 60$ days of age

Figure 5. Anatomical characteristics of the left and right testes of male Japanese quails, aged $35(n=12)$ and 60 days $(n=6)$, receiving diets with different crude protein levels during the growth phase. * Linear effect $(p<0.01)$. 

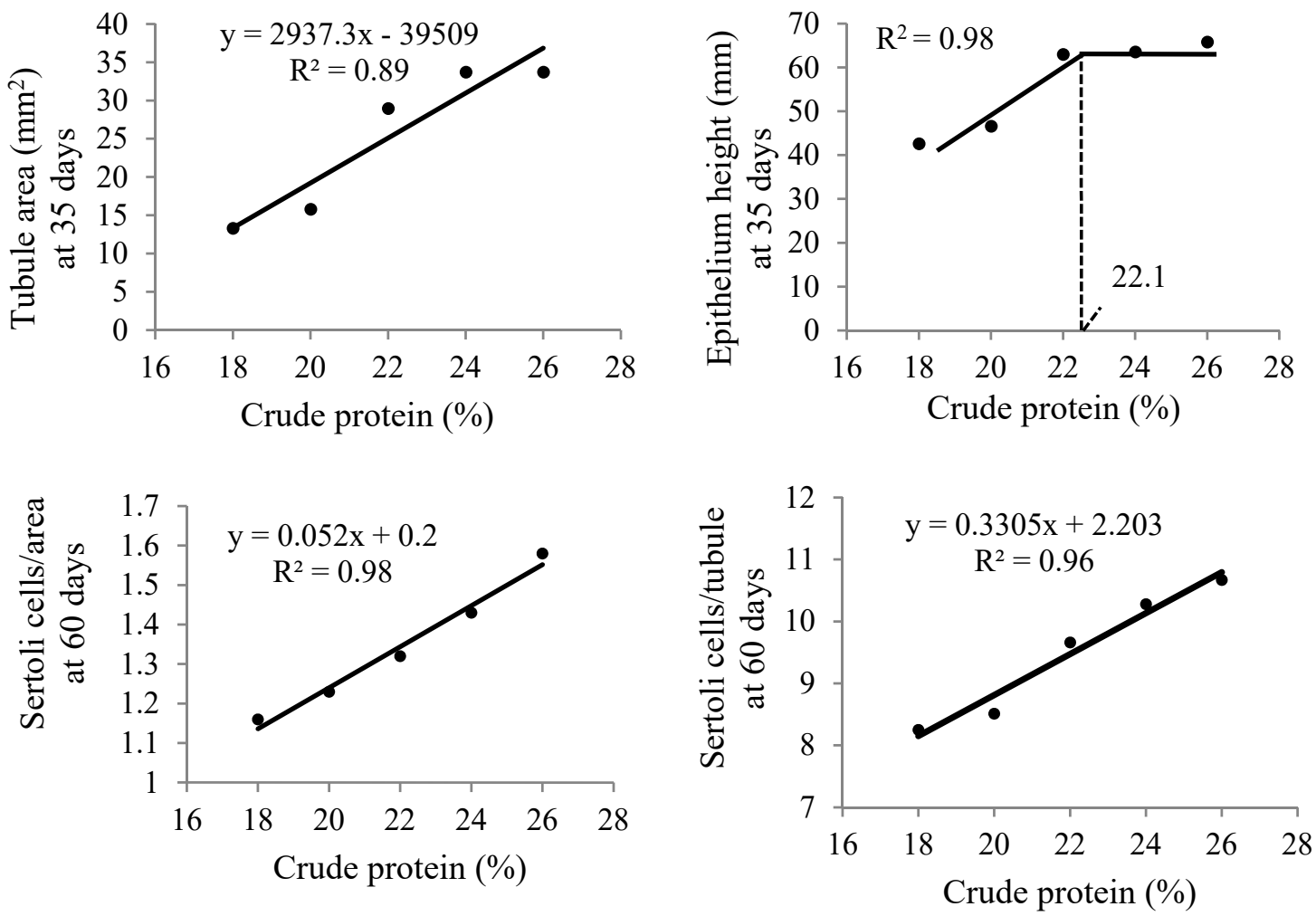

Figure 6. Seminiferous tubular area and testis germinal epithelial height at 35 days of age $(n=12)$ and number of Sertoli cells per area and per tubule at 60 days of age $(n=6)$ in Japanese quails receiving diets with different crude protein levels during the growing phase.

$\mathrm{CP}$ corn- and soybean meal-based diets recommended for Japanese quails in the growth phase by the NRC [4].

The protein requirements for bird body weight gain de- creased until 36 days of age, decreasing from $24 \%$ over the first two weeks to $20 \%$ at the end of the growth phase (Figure 4), which was also observed by Karaalp [28] and Wen et al

Table 6. Reproductive performance of male Japanese quails aged 90 days receiving diets with different crude protein levels during the growth phase $(n=6)$

\begin{tabular}{|c|c|c|c|c|c|c|c|}
\hline \multirow{2}{*}{ Variable } & \multicolumn{5}{|c|}{ Crude protein (\%) } & \multirow{2}{*}{ SEM } & \multirow{2}{*}{ p-value } \\
\hline & 18 & 20 & 22 & 24 & 26 & & \\
\hline Cloacal gland & 13.6 & 13.9 & 14.1 & 14.2 & 14.1 & 0.24 & 0.39 \\
\hline Height (mm) & 20.1 & 20.8 & 20.4 & 20.5 & 21.2 & 0.40 & 0.35 \\
\hline Width (mm) & 2.73 & 2.90 & 2.86 & 2.91 & 3.00 & 0.10 & 0.38 \\
\hline Area $\left(\mathrm{cm}^{2}\right)$ & 0.14 & 0.16 & 0.14 & 0.12 & 0.11 & $0.07 *$ & 0.67 \\
\hline Foam weight (g) & 1.62 & 1.65 & 1.69 & 1.71 & 1.55 & 0.12 & 0.87 \\
\hline Foam protein (g/dL) & 3.56 & 3.28 & 2.85 & 3.63 & 3.30 & 0.38 & 0.64 \\
\hline Semen volume $(\mathrm{mL})$ & 13.6 & 13.9 & 14.1 & 14.2 & 14.1 & 0.24 & 0.39 \\
\hline Semen concentration $\left(\times 10^{6} \mathrm{sptz} / \mu \mathrm{L}\right)$ & 1.41 & 1.43 & 1.30 & 1.45 & 1.68 & 0.20 & 0.75 \\
\hline \multicolumn{8}{|l|}{ Semen without foam } \\
\hline Motility (\%) & 67.9 & 67.1 & 64.1 & 70.4 & 68.9 & 3.60 & 0.79 \\
\hline Vigor & 3.14 & 3.07 & 3.03 & 3.35 & 3.06 & 0.15 & 0.59 \\
\hline Viability (\%) & 95.6 & 95.4 & 95.6 & 93.9 & 96.8 & 0.42 & 0.42 \\
\hline \multicolumn{8}{|l|}{ Semen with foam } \\
\hline Motility (\%) & 68.8 & 67.9 & 64.4 & 67.4 & 68.4 & 4.15 & 0.95 \\
\hline Vigor & 3.42 & 3.58 & 3.63 & 3.42 & 3.79 & 0.15 & 0.40 \\
\hline Viability (\%) & 95.7 & 86.1 & 96.3 & 94.3 & 95.3 & 0.44 & 0.84 \\
\hline Fertility (\%)*夫 & 91.7 & 89.8 & 94.4 & 95.4 & 90.7 & - & 0.56 \\
\hline
\end{tabular}

SEM, standard error of the mean.

* Box-Cox data transformation.

$\star \star n=100$. 
[22]. In addition, weight gain at the end of the growth phase (1 to 35 days) did not differ among birds receiving diets with $22 \%, 24 \%$, or $26 \%$ CP. This indicates that phased feeding is ideal for quails during the growth phase $[23,28]$ because dietary manipulation may be important in decreasing the nitrogen content in the excreta to ameliorate environmental emissions and respiratory problems in sheds [29]. The current recommendations proposed by Rostagno et al [23] are similar to the results presented here.

Improved knowledge of $\mathrm{CP}$ requirements for different animal species and categories through applying the concept of dietary formulations with ideal protein composition to optimize amino acid use is also needed. A decrease of greater than three or four percent in dietary $\mathrm{CP}$, even if the feed meets all the amino acid requirements, may result in low productive performance [30]. Thus, determining the true dietary CP requirements for male Japanese quails is essential to correctly apply the optimal protein concept to breeder flocks.

In this study, levels of $23 \% \mathrm{CP}$ or higher accelerated bodily and reproductive organ development during the growth phase, affecting the testis up to reproductive age. However, requirements for the chick and grower phases may differ, and further studies are needed to determine the viability of using specific formulations for each rearing phase. In addition, no need for specific dietary formulations in males was evident in this study.

In conclusion, dietary $\mathrm{CP}$ concentration affected body and testicular development in male Japanese quails but did not affect reproductive efficiency.

\section{CONFLICT OF INTEREST}

We certify that there is no conflict of interest with any financial organization regarding the material discussed in the manuscript.

\section{FUNDING}

The authors thank the Brazilian funding agencies, FAPEMIG (CVZ APQ 00996/14), CNPq (PQ 305478/2015-0) and CAPES (88881.030399/2013-01), for the financial support and the Department of Veterinary Medicine and Department of Animal Science of the Federal University of Lavras (UFLA) for use of the facilities needed to perform the present study.

\section{REFERENCES}

1. Wei HW, Hsieh TL, Chang SK, Chiu WZ, Huang YC, Lin MF. Apportioning protein requirements for maintenance v. growth for blue-breasted quail (Excalfactoria chinensis) from
7 to 21 days of age. Animal 2011;5:1515-20. https://doi.org/ 10.1017/S1751731111000590

2. Renema RA, Robinson FE, Newcombe M, McKay RI. Effects of body weight and feed allocation during sexual maturation in broiler breeder hens. 1. Growth and carcass characteristics. Poult Sci 1999;78:619-28. https://doi.org/10.1093/ps/78.5.619

3. Fontana EA, Weaver Jr WD, Van Krey HP. Effects of various feeding regimens on reproduction in broiler-breeder males. Poult Sci 1990;69:209-16. https://doi.org/10.3382/ps.0690209

4. NRC. National Research Council. Nutrient requirements of poultry: ninth revised edition. 9th ed. Washington, DC, USA: National Academies Press; 1994.

5. Rostagno HS, Albino LFT, Donzele JL, et al. Brazilian tables for poultry and swine: Composition of feedstuffs and nutritional requirements. 3 ed. Viçosa, MG, USA: Universidade Federal de Viçosa; 2011.

6. Bongalhardo DC. Production and preservation of rooster semen. Rev Bras Reprod Anim 2013;37:131-5.

7. Grieser DdO, Marcato SM, Furlan AC, et al. Estimation of growth parameters of body weight and body nutrient deposition in males and females of meat-and laying-type quail using the Gompertz model. Braz J Anim Sci 2018;47:e20170083. https://doi.org/10.1590/rbz4720170083

8. Albino LFT, Barreto SLT. Quail breeding for egg and meat production. 1 ed. Viçosa, MG, Brazil: Aprenda Fácil; 2003.

9. Barreto SLT, Quirino BJS, Brito CO, et al. Metabolizable energy levels for Japanese quails in the initial laying phase. Braz J Anim Sci 2007;36:79-85. https://doi.org/10.1590/ S1516-35982007000100010

10.AOAC. Official methods of analysis. 18th ed. Gaithersburg, MD, USA: Official Method: AOAC International; 2005.

11. Yadav S, Chaturvedi CM. Light colour and intensity alters reproductive/seasonal responses in Japanese quail. Physiol Behav 2015;147:163-8. https://doi.org/10.1016/j.physbeh. 2015.04.036

12. Khalil N, Bereznay O, Sporn M, Greenberg AH. Macrophage production of transforming growth factor beta and fibroblast collagen synthesis in chronic pulmonary inflammation. J Exp Med 1989;170:727-37. https://doi.org/10.1084/jem.170. 3.727

13. Suvarna KS, Layton C, Bancroft JD. Bancroft's theory and practice of histological techniques e-book. Amsterdam, Netherlands: Elsevier Health Sciences; 2019.

14. Reitemeier S, Hänse M, Hahn A, et al. Antibody selection for immunocytochemical characterization of the male reproductive system in Psittaciformes. Theriogenology 2013;80:597608. https://doi.org/10.1016/j.theriogenology.2013.05.027

15. Oznurlu Y, Sur E, Ozaydin T, Celik I, Uluisik D. Histological and histochemical evaluations on the effects of high incubation temperature on the embryonic development of tibial growth plate in broiler chickens. Microsc Res Tech 2016;79: 106-10. https://doi.org/10.1002/jemt.22611 
16.Ben-Ezra N, Burness G. Constant and cycling incubation temperatures have long-term effects on the morphology and metabolic rate of Japanese Quail. Physiol Biochem Zool 2017; 90:96-105. https://doi.org/10.1086/688383

17. Bhagat RP, Zade SB, Charde PN. Study on eggs of Japanese quail (Coturnix coturnix japonica) during incubation in the controlled laboratory conditions. J Appl Nat Sci 2012;4:856. https://doi.org/10.31018/jans.v4i1.228

18. Biswas A, Mohan J, Sastry KVH. Effect of dietary supplementation of vitamin $\mathrm{E}$ on production performance and some biochemical characteristics of cloacal foam in male Japanese quail. Anim Reprod Sci 2013;140:92-6. https://doi. org/10.1016/j.anireprosci.2013.05.008

19. Burrows WH, Quinn JP. The collection of spermatozoa from the domestic fowl and turkey. Poult Sci 1937;16:19-24. https:// doi.org/10.3382/ps.0160019

20.Fields MJ, Burns WC, Warnick AC. Age, season and breed effects on testicular volume and semen traits in young beef bulls. J Anim Sci 1979;48:1299-304. https://doi.org/10.2527/ jas1979.4861299x

21.Biswas A, Ranganatha OS, Mohan J. The effect of different foam concentrations on sperm motility in Japanese quail. Vet Med Int 2010;2010:Article ID 564921. https://doi.org/ 10.4061/2010/564921

22.Wen ZG, Du YK, Xie M, Li XM, Wang JD, Yang PL. Effects of low-protein diets on growth performance and carcass yields of growing French meat quails (France coturnix coturnix). Poult Sci 2017;96:1364-9. https://doi.org/10.3382/ps/pew321

23. Rostagno HS, Albino LFT, Donzele JL, et al. Brazilian tables for poultry and swine: Composition of feedstuffs and nutritional requirements. Viçosa, MG, Brazil: UFV; 2017.
24. Alves MG, Rato L, Carvalho RA, Moreira PI, Socorro S, Oliveira PF. Hormonal control of Sertoli cell metabolism regulates spermatogenesis. Cell Mol Life Sci 2013;70:77793. https://doi.org/10.1007/s00018-012-1079-1

25. Thurston RJ, Korn N. Spermiogenesis in commercial poultry species: anatomy and control. Poult Sci 2000;79:1650-68. https://doi.org/10.1093/ps/79.11.1650

26. Sarabia Fragoso J, Pizarro Díaz M, Abad Moreno JC, Casanovas Infesta P, Rodriguez-Bertos A, Barger K. Relationships between fertility and some parameters in male broiler breeders (body and testicular weight, histology and immunohistochemistry of testes, spermatogenesis and hormonal levels). Reprod Domest Anim 2013;48:345-52. https://doi.org/10.1111/j. 1439-0531.2012.02161.x

27.Perry TW, Cullison AE, Lowrey RS. Feeds and feeding. 6 ed. Upper Saddle River, NJ, USA: Pearson Education, Inc.; 2002.

28. Karaalp M. Effects of decreases in the three most limiting amino acids of low protein diets at two different feeding periods in Japanese quails. Br Poult Sci 2009;50:606-12. https:// doi.org/10.1080/00071660903260748

29. Alagawany M, El-Hack MEA, Laudadio V, Tufarelli V. Effect of low-protein diets with crystalline amino acid supplementation on egg production, blood parameters and nitrogen balance in laying Japanese quails. Avian Biol Res 2014;7:23543. https://doi.org/10.3184/175815514X14152945166603

30.Jariyahatthakij P, Chomtee B, Poeikhampha T, Loongyai W, Bunchasak C. Methionine supplementation of low-protein diet and subsequent feeding of low-energy diet on the performance and blood chemical profile of broiler chickens. Anim Prod Sci 2017;58:878-85. https://doi.org/10.1071/AN16258 